Cestre

Journal of Engineering Science and Technology Review 12 (6) (2019) 121 - 125

Research Article
JOURNAL OF

Engineering Science

and Technology Review

\title{
Compact MIMO Antenna with High Isolation for 5G Smartphone Applications
}

\author{
A.M. Ibrahim*, I.M. Ibrahim and N. A. Shairi
}

Centre for Telecommunication Research and Innovation (CeTRI), akultiKejuruteraanElektronik dan KejuruteraanKomputer, UniversitiTeknikal Malaysia Melaka (UTeM), Hang Tuah Jaya, 76100 Durian Tunggal, Melaka, Malaysia.

Received 14 August 2019; Accepted 27 December 2019

\begin{abstract}
A compact fractal multiple-input multiple-output (MIMO) antenna within the band range of 4.7-5 GHz was designed, and the fabrication and measurement outcomes derived from the use of the MIMO prototype revealed that the proposed MIMO antenna gave a better performance in terms of efficiency, isolation and the envelope correlation coefficient (ECC). Two radiating elements with high isolation have been proposed for $5 \mathrm{G}$ mobile smartphones. Here, a novel antenna, with a fractal $\mathrm{V}$-shape design and copper lining to enhance the isolation between two adjacent input ports, was configured via a six-stage process. The proposed dimensions of the antenna were $21 \times 24 \times 0.8 \mathrm{~mm} 3$, and it had an inexpensive FR4 substrate with a thickness of $0.8 \mathrm{~mm}$, a dielectric constant of 4.4 , and $0.035-\mathrm{mm}$ thick copper lining. The small and simple MIMO antenna demonstrated not only a high level of isolation but also a lower envelope correlation coefficient. These attributes are suitable for $5 \mathrm{G}$ smartphone applications, which are being introduced into Chinese markets. Both the simulated and measured results proved that the proposed method gives an excellent decoupling performance. A good impedance matching return loss of less than $10 \mathrm{~dB}$, high isolation of less then $-18.5 \mathrm{~dB}$ at the centre frequency, and low envelope correlation coefficient (ECC) that was above 0.05 were measured across the coveted operation bandwidth. The proposed MIMO array was simulated, and a prototype was fabricated and tested. The results showed that all the elements were able to cover the desired band range of $4.7-5 \mathrm{GHz}$.
\end{abstract}

Keywords: 5G band, Envelope correlation coefficient (ECC), Fractal antenna, Isolation, MIMO antenna

\section{Introduction}

The importance and recognition of ultra-wide bands, and the high level of demand for data and bandwidths for channels are being continuously considered in the interest of contemporary wireless systems. Single-input and single-output wireless applications[1]-[5], in addition to single-input multipleoutput applications, are being developed significantly into multiple-input multiple-output designs in all contemporary communication systems, thereby increasing the need for the integration of multiple antennae into user equipment. Several researchers have developed some research points in terms of polarization diversity, gain value, bandwidth level, and coupling reduction among inter-elements, and the required channel capacity as a result of considerable improvements in the design of multi-input multi-output (MIMO) antennae, and their obvious performance [6], [7].

Moreover, such designs additionally require reductions to multiple element antennae (MEA) to enable them to fit into and match robust user applications, and support multi-band runs for the reusability of the equipment in several different areas around the world. Improvements to the multi-band resonance and bandwidth of impedance have significantly allowed designers to develop modern antenna system networks. Besides, the development of radiation diversity has contributed to the reduction of the correlation factor, and improved the performance level of the MIMO system. MIMO

*E-mail address: ayman971972@gmail.com

ISSN: 1791-2377 $\bigodot 2019$ School of Science, IHU. All rights reserved.

doi:10.25103/iestr.126.15 wireless systems can provide a considerable surge in capacity without the need to increase the spectrum or transmission power [8]-[13].

A MIMO monopole antenna with a ground branch decoupling structure of less than $0.01 \mathrm{ECC}$, a low mutual coupling, and more than $20 \mathrm{~dB}$ of high isolation was also proposed by [14]. Covering a band range of 2.2-2.48 GHz, this dual polarized MIMO antenna system, which was comprised of four orthogonal thin copper dipoles [15], was also discovered to have been popularly used in high-order decoupling modes [16].

MIMO antenna elements that had been placed in the constant null-amplitude field points were also found to have given rise to an enhanced isolation as a result of their respective applications from the decoupling network-based method [17] on a pair of narrow and wide slots as well as the two decoupling devices with an inverted T-shaped etched slot and a meandering resonant branch for the lower and higher bands.

Besides the use of a compact split-ring resonator (SRR) structure and a planar spiral line (PSL) in the resonance structure method [18]-[20], a high level of isolation was also observed by changing the electrical length of the radiators through the pattern diversity technique [6], [21], and decreasing the mutual coupling of the ordered pairs with the introduction of the orthogonal mode [22], although the latter condition can also be achieved by implementing the decoupling network [17], pattern diversity technique [6], [21], ground slot structure [23], hybrid techniques between defected ground structure and neutralization lines [24], a 
A.M. Ibrahim, I.M. Ibrahim and N. A. Shairi/Journal of Engineering Science and Technology Review 12 (6) (2019) 121 - 125

resonance structure [18]-[20] and those of defected ground structures [25], [26].

The focus on smart device miniaturization would require less space for antenna design, and consequently, this will affect the close association between isolation and bandwidth in the MIMO antenna system. As such, this paper attempted to solve the above-mentioned issues with a high isolation printed on two-element arrays operating in the centre frequency of $4.85 \mathrm{GHz}$ in the band range of $4.7-5 \mathrm{GHz}$. With this in mind, the MIMO antenna, which consisted of two elements, was placed symmetrically on the frame with the grounded neutralization lines of the hybrid decoupling structures generating a high isolation level. As shown in Table 1 , the proposed decoupling design of the small antenna, when compared to the other two-element MIMO designs, exhibited a higher level of isolation and ECC.

Table 1. Comparison of previously published literature

\begin{tabular}{|c|c|c|c|c|c|c|}
\hline Ref. & $\begin{array}{c}\text { Size }\left(\mathrm{mm}^{2}\right), \\
\text { material, } \\
\text { number of ports }\end{array}$ & $\begin{array}{l}\text { Bandwidth } \\
\text { (GHz), } \\
\text { (dB) }\end{array}$ & $\begin{array}{l}\text { Isolation } \\
\text { (dB) }\end{array}$ & ECC & Decoupling method & Weak points \\
\hline$[27]$ & $\begin{array}{c}40 \times 80, \\
\text { FR4 substrate, } \\
(2 \text {-element })\end{array}$ & $\begin{array}{l}(3.1-12) \\
(-6 \mathrm{~dB})\end{array}$ & -11 & $\begin{array}{c}\text { Not } \\
\text { mentioned }\end{array}$ & Neutralization lines & $\begin{array}{c}\text { Medium structure, ECC value } \\
\text { not mentioned, low isolation } \\
\text { value, large size, and impedance } \\
\text { bandwidth of - } 6 \mathrm{~dB}\end{array}$ \\
\hline [28] & $\begin{array}{c}40 \times 40 \\
- \\
(2 \text { - elements })\end{array}$ & $\begin{array}{c}(6-9) \\
(-10 \mathrm{~dB})\end{array}$ & -15 & - & Decoupling Network & $\begin{array}{c}\text { Complex structure, no ECC } \\
\text { value, low isolation value, large } \\
\text { size. }\end{array}$ \\
\hline [29] & $\begin{array}{c}26 \times 46 \times 0.8, \text { FR } 4 \\
\text { substrate } \\
(2 \text { - elements })\end{array}$ & $\begin{array}{l}(3.4-3.8) \\
(-10 \mathrm{~dB})\end{array}$ & -19 & 0.007 & $\begin{array}{c}\text { Hyper } \\
\text { (neutralization lines and } \\
\text { Defected ground) }\end{array}$ & $\begin{array}{c}\text { Very complex structure and } \\
\text { large size }\end{array}$ \\
\hline$[30]$ & $\begin{array}{c}31 \times 31, \\
\text { FR4 substrate, }(2- \\
\text { elements }) \\
(3.1-3.55)\end{array}$ & $\begin{array}{l}(3.1-3.55) \\
\text { and }(4.4- \\
4.99)\end{array}$ & $\begin{array}{l}-10 \\
-19\end{array}$ & $\begin{array}{l}0.01 \\
0.005\end{array}$ & $\begin{array}{c}\text { Hyper } \\
\text { (neutralization lines and } \\
\text { Defected ground) }\end{array}$ & $\begin{array}{c}\text { Very complex structure and } \\
\text { large size }\end{array}$ \\
\hline [31] & $\begin{array}{l}115 \times 60 \\
\text { FR4 substrate, } \\
(2 \text { - elements })\end{array}$ & $\begin{array}{l}(1.66-2.84) \\
\quad(-10 \mathrm{~dB})\end{array}$ & -15 & 0.3 & Neutralization & $\begin{array}{c}\text { Medium structure, high ECC } \\
\text { value, low isolation value, large } \\
\text { size }\end{array}$ \\
\hline$[32]$ & $\begin{array}{l}140 \times 70 \\
\text { FR4 substrate } \\
(8 \text { - elements })\end{array}$ & $\begin{array}{l}(3.4-3.6) \\
(-10 \mathrm{~dB})\end{array}$ & -10 & 0.2 & Neutralization lines & $\begin{array}{c}\text { Simple structure, high ECC } \\
\text { value, low isolation value }\end{array}$ \\
\hline [33] & $\begin{array}{c}136 \times 68, \\
\text { FR4 substrate, } \\
(8 \text { - elements })\end{array}$ & $\begin{array}{l}(2.55-2.65) \\
(-6 \mathrm{~dB})\end{array}$ & -12 & 0.15 & - & $\begin{array}{l}\text { Simple structure, high ECC } \\
\text { value, low isolation value, and } \\
\text { impedance bandwidth is }-6 \mathrm{~dB}\end{array}$ \\
\hline [34] & $\begin{array}{l}124 \times 74, \\
\text { FR4 substrate, } \\
(8-\text { element })\end{array}$ & $\begin{array}{c}(3.3-3.6) \\
(-6 \mathrm{~dB})\end{array}$ & -15 & 0.15 & $\begin{array}{l}\text { Hyper decoupling } \\
\text { (neutralization and } \\
\text { Defected ground) }\end{array}$ & $\begin{array}{l}\text { Simple structure, high ECC } \\
\text { value and impedance bandwidth } \\
\text { is }-6 \mathrm{~dB}\end{array}$ \\
\hline [35] & $\begin{array}{l}120 \times 60, \\
\text { Rogers R04003c, } \\
(8-\text { elements })\end{array}$ & $\begin{array}{l}(3.4-3.6) \\
(-6 \mathrm{~dB})\end{array}$ & - & - & - & $\begin{array}{l}\text { Medium structure, no ECC } \\
\text { value, no isolation value, large } \\
\text { size, expansive material, and }\end{array}$ \\
\hline [36] & $\begin{array}{l}\quad 136 \times 68 \\
\text { FR4 substrate, } \\
(8 \text { - elements })\end{array}$ & $\begin{array}{l}(2.55-2.65) \\
(-6 \mathrm{~dB})\end{array}$ & -12.5 & 0.15 & Polarization orthogonal & $\begin{array}{l}\text { Simple structure, high ECC } \\
\text { value and impedance bandwidth } \\
\text { is }-6 \mathrm{~dB}\end{array}$ \\
\hline [37] & $\begin{array}{l}150 \times 75, \\
\text { FR4 substrate, } \\
(8-\text { elements })\end{array}$ & $\begin{array}{l}(3.4-3.6) \\
(-6 \mathrm{~dB})\end{array}$ & -10 & 0.15 & Neutralization lines & $\begin{array}{l}\text { Medium structure, high ECC } \\
\text { value, low isolation value and } \\
\text { impedance bandwidth is }-6 \mathrm{~dB}\end{array}$ \\
\hline [21] & $\begin{array}{c}160 \times 68.8 \\
\text { FR4 substrate, } \\
(8-\text { elements })\end{array}$ & $\begin{array}{c}(3.45-3.59) \\
(-6 \mathrm{~dB})\end{array}$ & -15 & 0.08 & Pattern diversity & $\begin{array}{l}\text { Simple structure, low isolation } \\
\text { value and impedance bandwidth } \\
\text { is }-6 \mathrm{~dB}\end{array}$ \\
\hline [38] & $\begin{array}{l}140 \times 70 \times 0.8 \\
\text { FR4 } \\
\text { substrate, }(10- \\
\text { elements })\end{array}$ & $\begin{array}{l}(3.4-3.8) \\
(-6 \mathrm{~dB})\end{array}$ & -10 & 0.1 & Neutralization lines & $\begin{array}{l}\text { Simple structure, high ECC } \\
\text { value, low isolation value and } \\
\text { impedance bandwidth is }-6 \mathrm{~dB}\end{array}$ \\
\hline [9] & $\begin{array}{l}\quad 140 \times 70, \\
\text { FR4 substrate, } \\
(10-\text { elements })\end{array}$ & $\begin{array}{l}(3.4-3.8) \\
(-6 \mathrm{~dB})\end{array}$ & -10 & 0.1 & - & $\begin{array}{l}\text { Simple structure, high ECC } \\
\text { value, low isolation value, large } \\
\text { size, and impedance bandwidth } \\
\text { is }-6 \mathrm{~dB}\end{array}$ \\
\hline$[12]$ & $\begin{array}{c}150 \times 75 \\
\text { FR4 substrate, } \\
(12 \text { - elements })\end{array}$ & $\begin{array}{l}(3.4-3.6) \\
(-6 \mathrm{~dB})\end{array}$ & -12.5 & 0.2 & Polarization orthogonal & $\begin{array}{l}\text { Medium structure, high ECC } \\
\text { value and impedance bandwidth } \\
\text { is }-6 \mathrm{~dB}\end{array}$ \\
\hline [11] & $\begin{array}{l}150 * 75 \\
\text { FR4 substrate, } \\
\text { (8 and } 16 \text { elements) }\end{array}$ & $\begin{array}{l}(3.4-3.6) \\
(-6 \mathrm{~dB})\end{array}$ & -10 & 0.32 & Neutralization & $\begin{array}{l}\text { Simple structure, high ECC } \\
\text { value, low isolation value and } \\
\text { impedance bandwidth is }-6 \mathrm{~dB}\end{array}$ \\
\hline [39] & $\begin{array}{l}150 \times 57 \times 0.8 \\
\text { FR4 substrate, }(16- \\
\text { elements })\end{array}$ & $\begin{array}{c}(3.4-3.6) \\
(-6 \mathrm{~dB})\end{array}$ & -10 & 0.3 & Neutralization lines & $\begin{array}{l}\text { Medium structure, high ECC } \\
\text { value and impedance bandwidth } \\
\text { is }-6 \mathrm{~dB}\end{array}$ \\
\hline$[40]$ & $\begin{array}{l}74 \times 74, \\
\text { Rogers, RO4350b, } \\
\text { Three layers, } \\
(24 \text { - elements })\end{array}$ & $\begin{array}{l}(3.45-3.55) \\
(-6 \mathrm{~dB})\end{array}$ & -15 & 0.1198 & - & $\begin{array}{l}\text { Very complex structure, high } \\
\text { ECC value, low isolation value, } \\
\text { expansive material, size and } \\
\text { impedance bandwidth is }-6 \mathrm{~dB}\end{array}$ \\
\hline $\begin{array}{l}\text { This } \\
\text { study }\end{array}$ & $\begin{array}{c}24 \times 21 \times 0.8, \text { FR } 4 \\
\text { substrate, }\end{array}$ & $\begin{array}{l}(4.7-5) \\
(-10 \mathrm{~dB})\end{array}$ & -18.5 & 0.002 & $\begin{array}{c}\text { Hyper } \\
\text { (neutralization lines and }\end{array}$ & - \\
\hline
\end{tabular}




\begin{tabular}{c|c|c|c|c|c|c}
\hline Ref. & $\begin{array}{c}\text { Size }\left(\mathbf{m m}^{2}\right), \\
\text { material, } \\
\text { number of ports }\end{array}$ & $\begin{array}{c}\text { Bandwidth } \\
(\mathbf{G H z}), \\
(\mathbf{d B})\end{array}$ & $\begin{array}{c}\text { Isolation } \\
(\mathbf{d B})\end{array}$ & ECC & Decoupling method & Weak points \\
\hline & (2- elements) & & & & Defected ground) & \\
\hline
\end{tabular}

\section{Antenna Design}

Initially, a mutated square patch, that was half the size of the one used in the previous stage, was added to shape the fractal antenna. The designing of the proposed fractal printed monopole antenna started with a V-shaped initiator, which consisted of a radiating patch with overall dimensions of $(7 \times 6) \mathrm{mm}$ printed on a substrate with dimensions of $(\mathrm{Wp} \times \mathrm{Lt}) \mathrm{mm}$, fixed on the FR4 material with a dielectric constant of 4.4 and a copper lining thickness of $h=0.8 \mathrm{~mm}$. The antenna was fed through a microstrip line with a length of (Lf) $\mathrm{mm}$ and a width of (Wf) $\mathrm{mm}$ designed characteristically for $50 \Omega$. On the other side of the substrate, a ground plane was printed with dimensions of $(6.8 \times 8) \mathrm{mm}$. The gap between the rectangular patch and the ground plane was $\mathrm{gI}=1.2 \mathrm{~mm}$. The geometry of the reference antenna is shown in Fig. 3a. The geometry of the V-shaped initiator antenna is shown in Fig. 3b. Table 2 illustrates the parameters and dimensions of the antenna. $\lambda \mathrm{g}$ and $\in$ eff were calculated using Eq. 1 and Eq. 2, respectively, and then, the lower resonant frequency, $\mathrm{fL}$ relative to the radiating patch was determined using Eq. 3:

$$
\begin{aligned}
& \lambda_{g}=\frac{\lambda_{0}}{\sqrt{\epsilon_{\text {eff }}}} \\
& \epsilon_{\text {eff }}=\left(\frac{\epsilon_{r}+1}{2}\right)+\left(\frac{\epsilon_{r}-1}{2}\right)\left(1+\frac{12 h}{w f}\right)^{\frac{-1}{2}} \\
& f_{L}=\frac{C}{1.7 \sqrt{\epsilon_{\text {eff }(L t-L g+s 0)}}}
\end{aligned}
$$

where $\lambda_{0}$ is the free space wavelength, $\epsilon_{r}$ is the dielectric constant, $\varepsilon_{e f f}$ is the effective dielectric constant of the substrate, $w f$ is the width of the e feed line, $h$ is the height of the FR-4 substrate, and S is the value of the overlap between the scaled-down copies [3], [5], [41]. (a)

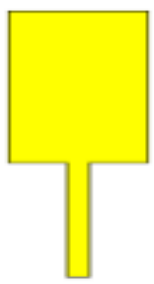

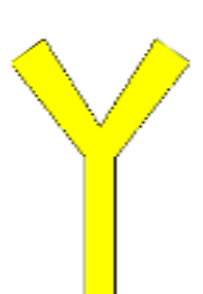

(b)

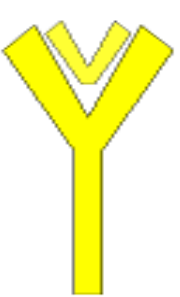

(c)

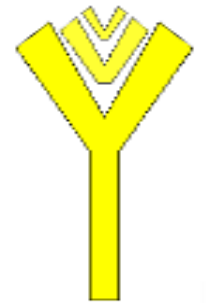

(d)
Fig. 1. Cell configuration process for V-shaped antenna (a) Stage 1, (b) Stage 2, (c) Stage 3, and (d) Stage 4

Table 2 displays all the dimensions of the proposed MIMO antenna. Each radiating element of the two-element MIMO antenna held a symmetrical monopole antenna fed by a $50 \Omega$ microstrip line. This microstrip line held two 7-mm closed-space monopoles printed on a $24 \times 21 \mathrm{~mm}$ (FR-4) substrate, as exhibited in Fig. 2. To obtain high isolation, neutralization lines were inserted between the two separated antennae of the patch plane. This complemented the two vertical lines of the patch plane, with a width of w $8=0.3$ and length of $\mathrm{L} 8=21$, and a vertical line of width $\mathrm{L} 24=0.2$ and

\begin{tabular}{|c|c|c|c|c|c|c|}
\hline Parameters & $\mathbf{L t}$ & wt & Lf & Wf & m1 & m2 \\
\hline $\begin{array}{c}\text { Dimensions } \\
(\mathrm{mm})\end{array}$ & 21 & 24 & 8 & 1.27 & 6.26 & 3.13 \\
\hline Parameters & $\mathrm{m} 4$ & $\mathrm{~m} 5$ & $\mathrm{~m} 6$ & $\mathrm{~m} 7$ & $\mathrm{~m} 8$ & $\mathrm{~m} 9$ \\
\hline $\begin{array}{l}\text { Dimensions } \\
(\mathrm{mm})\end{array}$ & 5.08 & 2.54 & 1.27 & 21 & 21 & 3.48 \\
\hline Parameters & w1 & w2 & w3 & w4 & w5 & w6 \\
\hline $\begin{array}{l}\text { Dimensions } \\
(\mathrm{mm})\end{array}$ & 2.5 & 1.25 & 0.63 & 2 & 1 & 0.5 \\
\hline Parameters & w8 & w9 & w10 & $\mathrm{S} 1$ & S2 & S3 \\
\hline $\begin{array}{l}\text { Dimensions } \\
(\mathrm{mm})\end{array}$ & 0.3 & 2.07 & 8 & 1.3 & 2.64 & 1.67 \\
\hline Parameters & $\mathrm{m} 3$ & $\mathrm{~m} 10$ & w7 & & & \\
\hline $\begin{array}{l}\text { Dimensions } \\
(\mathrm{mm})\end{array}$ & 1.57 & 3.5 & 1 & & & \\
\hline
\end{tabular}
length L16 $=13$ on the ground plane, as shown in Fig. 2 .
Table 2. Parameters and dimensions of the MIMO antenna

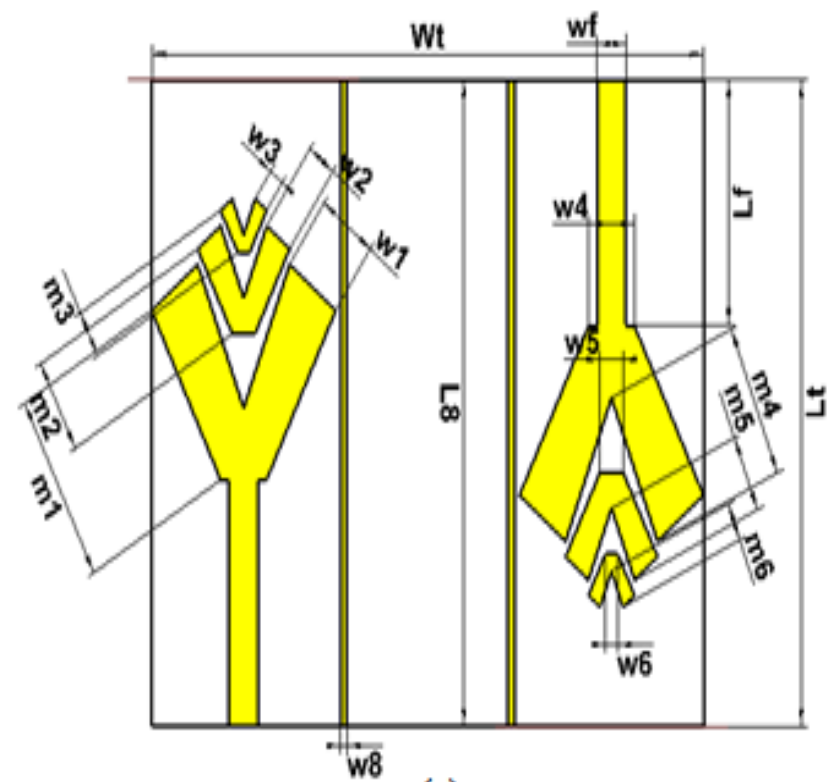

(a)

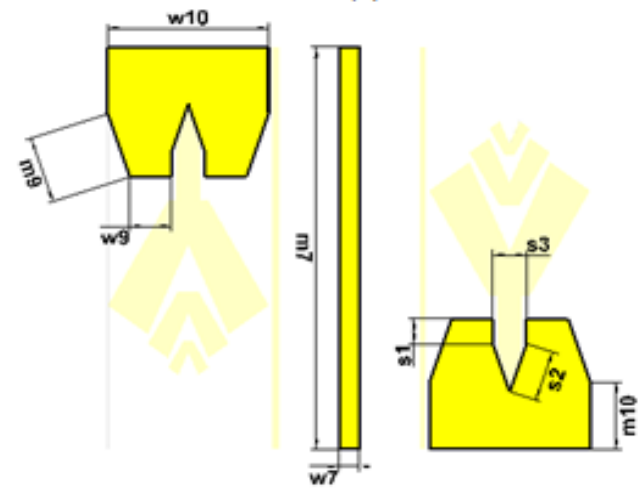

(b)

Fig. 2. Proposed design geometry of the MIMO antenna (a) Front View and (b) Back View

\section{Simulation Results}

The self-similarity property of the fractal shape was used to construct the structure of the multi-frequency antenna to 
A.M. Ibrahim, I.M. Ibrahim and N. A. Shairi/Journal of Engineering Science and Technology Review 12 (6) (2019) 121 - 125

realize the required band. Therefore, fractal geometries were applied to the first iteration of the V-shaped structure, and the resonance elements, which were scaled-down copies of the original element, were added to the top edges of the shape, as illustrated in Fig. 2. Then, by observing the return loss response, it was shown that the matching in the band from 4.7 $\mathrm{GHz}$ to $5 \mathrm{GHz}$ was good. Fig. 3 shows the reflection coefficients and transmission coefficients.

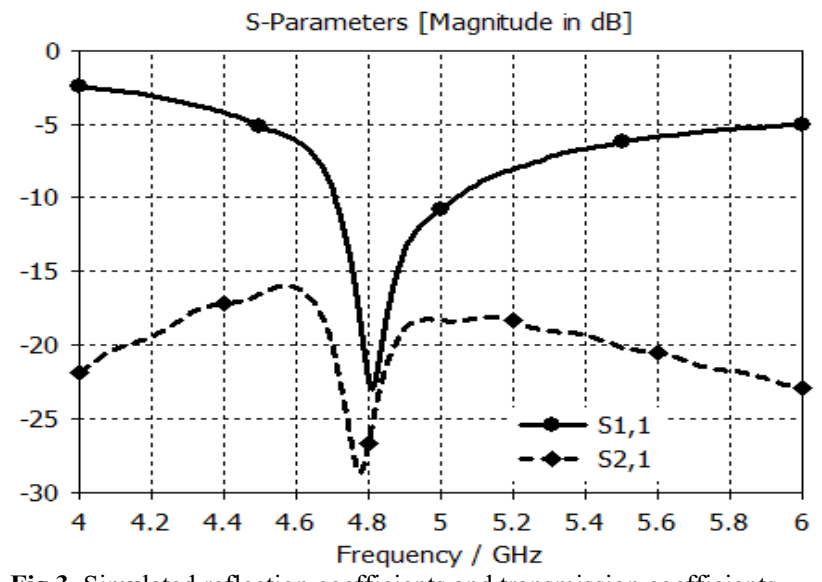

Fig 3. Simulated reflection coefficients and transmission coefficients

\section{Measured Results}

By fabricating a mobile antenna prototype for the band range of 4.7-5 GHz with a centre frequency of $4.85 \mathrm{GHz}$ from an inexpensive FR4 dielectric with overall dimensions of $21 \times$ $24 \times 0.8 \mathrm{~mm}^{3}$, as shown in Fig. 4, the simulated and measured reflection and transmission coefficients demonstrated by the two representative antennae (antenna 1 and antenna 2) in Fig. 5, were therefore implied to have a similar level of performance.

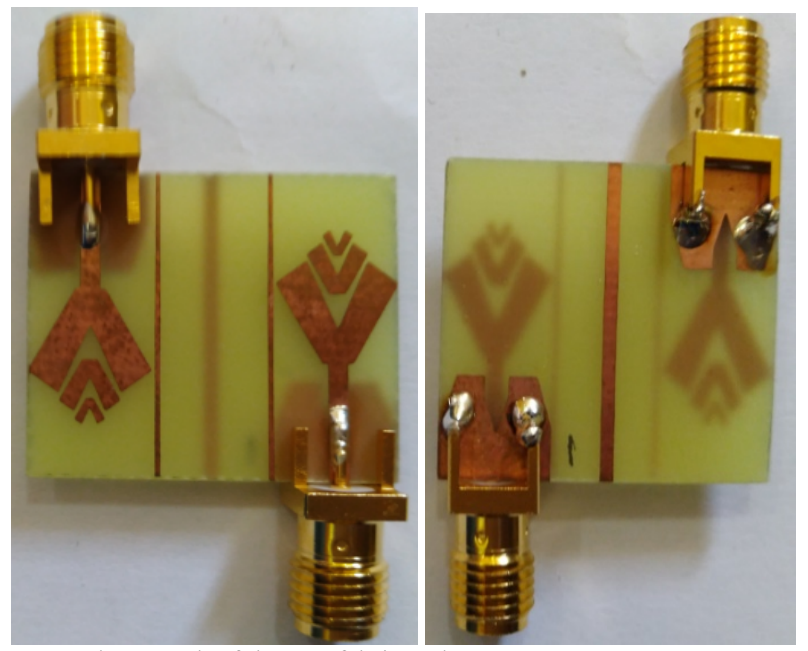

Fig. 4. Photograph of the two fabricated antennae

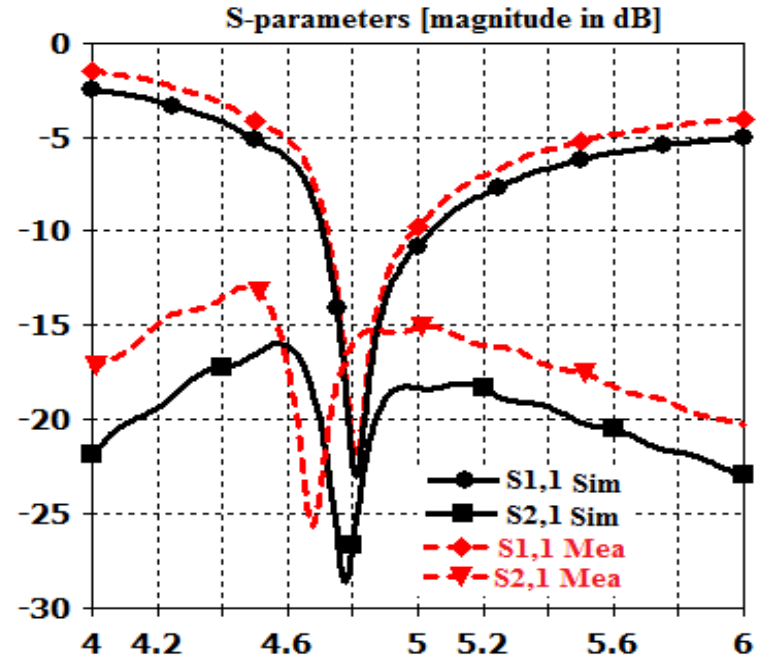

Fig. 5. Simulated and measured transmission coefficients and reflection coefficients

\section{Conclusion}

A mobile phone with a two-element antenna design was proposed for the use of $5 \mathrm{G}$ MIMO communications. This job involved the simulation and fabrication of a novel fractal MIMO antenna for the band range of 4.7-5 GHz. The different bands were controlled by way of the application of decoupling neutralization. Besides enhancing the isolation between the antenna elements, the ECC between the signals received by the MIMO antenna ports was sufficiently reduced to meet the specifications for $5 \mathrm{G}$ applications.

\section{Acknowledgment}

The authors would like to thank universiti Teknikal Malaysia Melaka (UTeM) and Ministry of Higher Education for sponsoring this work under research grants PJP/2017/FKEKK/HI10/S01529.

This is an Open Access article distributed under the terms of the Creative Commons Attribution License

\section{References}

[1] H. Alsariera, Z. Zakaria, and A. Awang Md Isa, "A Broadband PShaped Circularly Polarized Monopole Antenna With a Single Parasitic Strip," IEEE Antennas Wirel. Propag. Lett., vol. 18, no. 10, pp. 2194-2198, 2019.

[2] H. S. M. Sariera, Z. Zakaria, and A. A. M. Isa, "Broadband CPWFed Monopole Antenna for Indoor Applications," J. Telecommun. Electron. Comput. Eng., vol. 10, no. 2-6, pp. 31-34, 2018.
[3] A. M. Ibrahim, I. M. Ibrahim, and N. A. Shairi, "Design a Compact Wide Bandwidth of a Printed Antenna using Defected Ground Structure," J. Adv. Res. Dyn. Control Syst, vol. 11, no. 02, pp. 10651076, 2019.

[4] A. M. Ibrahim, I. M. Ibrahim, and N. A. Shair, "A Compact Quad Bands-Notched Monopole antenna for Ultra-Wideband Wireless Communicatione," RELIGACION, vol. No 17, no. 17,julio, pp. 815- 


\section{A.M. Ibrahim, I.M. Ibrahim and N. A. Shairi/Journal of Engineering Science and Technology Review 12 (6) (2019) 121 - 125} 24, 2019.

[5] A. M. Ibrahim, I. M. Ibrahim, and N. A. Shair, "A Compact Sextuple Multi-Band Printed Monopole Antenna," Opcion, vol. 86, pp. 1448$1467,2018$.

[6] A. Boukarkar, X. Q. Lin, Y. Jiang, L. Y. Nie, P. Mei, and Y. Q. Yu, "A miniaturized extremely close-spaced four-element dual-band MIMO antenna system with polarization and pattern diversity," IEEE Antennas Wirel. Propag. Lett., vol. 17, no. 1, pp. 134-137, 2018.

[7] K. Qian, L. Zhao, and K. L. Wu, "An LTCC Coupled Resonator Decoupling Network for Two Antennas," IEEE Trans. Microw. Theory Tech., vol. 63, no. 10, pp. 3199-3207, 2015.

[8] Y. Li, C. Y. D. Sim, Y. Luo, and G. Yang, "12-Port 5G Massive MIMO Antenna Array in Sub-6GHz Mobile Handset for LTE Bands 42/43/46 Applications," IEEE Access, vol. 6, no. c, pp. 344-354, 2017.

[9] K.-L. Wong and J.-Y. Lu, "3.6-GHz 10-antenna array for MIMO operation in the smartphone," Microw. Opt. Technol. Lett, vol. 57, no. 7, pp. 1699-1704, 2015.

[10]Y. L. Ban, C. Li, C. Y. D. Sim, G. Wu, and K. L. Wong, "4G/5G Multiple Antennas for Future Multi-Mode Smartphone Applications," IEEE Access, vol. 4, no. c, pp. 2981-2988, 2016.

[11] and Y.-L. B. K. L.Wong, J.-Y. Lu, L.-Y. Chen, W.-Y. Li, "8antenna and 16-antenna arrays using the quad-antenna linear array as a building block for the 3.5-GHz LTE MIMO operation in the smartphone," Microw. Opt. Technol. Lett, vol. 58, no. 1, pp. 174181, 2016.

[12] M. Y. Li, Y. L. Ban, Z. Q. Xu, J. Guo, and Z. F. Yu, "Tri-Polarized 12-Antenna MIMO Array for Future 5G Smartphone Applications," IEEE Access, vol. 6, pp. 6160-6170, 2018.

[13]K. L. Wong, C. Y. Tsai, and J. Y. Lu, "Two Asymmetrically Mirrored Gap-Coupled Loop Antennas as a Compact Building Block for Eight-Antenna MIMO Array in the Future Smartphone," IEEE Trans. Antennas Propag., vol. 65, no. 4, pp. 1765-1778, 2017.

[14] J. Prakash, V. Roshan, and S. Natarajamani, "MIMO Antenna for mobile terminals with enhanced isolation in LTE band," 2017 Int. Conf. Adv. Comput. Commun. Informatics, ICACCI 2017, vol. 2017Janua, pp. 2231-2234, 2017.

[15]H. Huang, X. Li, and Y. Liu, "5G MIMO antenna based on vector synthetic mechanism," IEEE Antennas Wirel. Propag. Lett., vol. 17, no. 6, pp. 1052-1055, 2018.

[16]X. Zhao, S. P. Yeo, and L. C. Ong, "Decoupling of Inverted-F Antennas with High-Order Modes of Ground Plane for 5G Mobile MIMO Platform," IEEE Trans. Antennas Propag., vol. 66, no. 9, pp. 4485-4495, 2018.

[17]C. Ding et al., "A Compact Dual-Band MIMO Slot Antenna for WLAN Applications," 2018 IEEE Antennas Propag. Soc. Int. Symp. Usn. Natl. Radio Sci. Meet. APSURSI 2018 - Proc., pp. 461-462, 2018.

[18] J. H. Xun, L. F. Shi, W. R. Liu, G. X. Liu, and S. Chen, "Compact Dual-Band Decoupling Structure for Improving Mutual Coupling of Closely Placed PIFAs," IEEE Antennas Wirel. Propag. Lett., vol. 16, no. c, pp. 1985-1989, 2017.

[19]A. Ramachandran, S. Valiyaveettil Pushpakaran, M. Pezholil, and V. Kesavath, "A Four-Port MIMO Antenna Using Concentric Square-Ring Patches Loaded with CSRR for High Isolation," IEEE Antennas Wirel. Propag. Lett., vol. 15, no. c, pp. 1196-1199, 2016.

[20]C. D. Xue, X. Y. Zhang, Y. F. Cao, Z. Hou, and C. F. Ding, "MIMO Antenna Using Hybrid Electric and Magnetic Coupling for Isolation Enhancement," IEEE Trans. Antennas Propag., vol. 65, no. 10, pp. 5162-5170, 2017.

[21]C. F. Ding, X. Y. Zhang, C. D. Xue, and C. Y. D. Sim, "Novel Pattern-Diversity-Based Decoupling Method and Its Application to Multielement MIMO Antenna," IEEE Trans. Antennas Propag., vol. 66, no. 10, pp. 4976-4985, 2018.

[22] L. Sun, H. Feng, Y. Li, and Z. Zhang, "Compact 5G MIMO mobile phone antennas with tightly arranged orthogonal-mode pairs," IEEE
Trans. Antennas Propag., vol. 66, no. 11, pp. 6364-6369, 2018.

[23] M. S. Sharawi, M. Ikram, and A. Shamim, "A Two Concentric Slot Loop Based Connected Array MIMO Antenna System for $4 \mathrm{G} / 5 \mathrm{G}$ Terminals," IEEE Trans. Antennas Propag., vol. 65, no. 12, pp. 6679-6686, 2017.

[24] A. M. Ibrahim, I. M. Ibrahim, and N. A. Shairi, “COMPACT MIMO SLOT ANTENNA OF DUAL-BANDS FOR LTE AND 5G APPLICATIONS.," Int. J. Adv. Sci. Technol., vol. 28, no. 13, pp. 239-246, 2019.

[25]J. Dong, X. Yu, and L. Deng, "A Decoupled Multiband DualAntenna System for WWAN/LTE Smartphone Applications," IEEE Antennas Wirel. Propag. Lett., vol. 16, no. c, pp. 1528-1532, 2017.

[26] J. Deng, J. Li, L. Zhao, and L. Guo, "A Dual-Band Inverted-F MIMO Antenna with Enhanced Isolation for WLAN Applications," IEEE Antennas Wirel. Propag. Lett., vol. 16, no. c, pp. 2270-2273, 2017.

[27]Y. Yu, X. Liu, Z. Gu, and L. Yi, "A Compact Printed Monopole Array with Neutralization Line for UWB Applications," IEEE Int. Symp. Antennas Propag., pp. 1779-1780, 2016.

[28]R. Xia, S. Qu, S. Member, P. Li, Q. Jiang, and Z. Nie, “An Efficient Decoupling Feeding Network for Microstrip Antenna Array," IEEE Antennas Wirel. Propag. Lett., vol. 1225, no. c, pp. 1-4, 2015.

[29] A. M. Ibrahim, I. M. Ibrahim, and N. A. Shairi, "Compact MIMO slots antenna design with different bands and high isolation for $5 \mathrm{G}$ smartphone applications," Baghdad Sci. J., vol. 16, no. 4, pp. $1093-$ $1102,2019$.

[30] A. M. Ibrahim, I. M. Ibrahim, and N. A. Shairi, "A.M. Ibrahim, I.M. Ibrahim, N. A. Shairi Centre for Telecommunication Research and Innovation (CeTRI), FakultiKejuruteraanElektronik dan KejuruteraanKomputer, UniversitiTeknikal Malaysia Melaka (UTeM), Hang Tuah Jaya, 76100 Durian,” vol. 28, no. 13, pp. 239246, 2019.

[31] Y. Wang and Z. Du, "A wideband printed dual-antenna with three neutralization lines for mobile terminals," IEEE Trans. Antennas Propag., vol. 62, no. 3, pp. 1495-1500, 2014.

[32] Y. Ban, C. Li, C. Sim, S. Member, and G. Wu, "4G / 5G Multiple Antennas for Future Multi-Mode Smartphone Applications," IEEE Access, vol. 3536, no. c, 2016.

[33]M. Li et al., "Eight-Port Orthogonally Dual-Polarized Antenna Array for 5G Smartphone Applications," IEEE Trans. Antennas Propag., vol. 64, no. 9, pp. 3820-3830, 2016.

[34] W. Jiang, B. Liu, Y. Cui, and W. Hu, "High-Isolation Eight-Element MIMO Array for 5G Smartphone Applications," IEEE Access, vol. 7, pp. 34104-34112, 2019.

[35]F. Report et al., "EIGHT-ELEMENT ANTENNA ARRAY FOR DIVERSITY AND MIMO MOBILE TERMI- NAL IN LTE 3500 MHz BAND," vol. 56, no. 6, pp. 1323-1327, 2014.

[36] M.-Y. Li, Z.-Q. Xu, Y.-L. Ban, C.-Y.-D. Sim, and Z.-F. Yu, "Eightport orthogonally dual-polarised MIMO antennas using loop structures for 5G smartphone," IET Microwaves, Antennas Propag., vol. 11 , no. 12, pp. 1810-1816, 2017.

[37] K. Wong, C. Tsai, S. Member, and J. Lu, "Two Asymmetrically Mirrored Gap-Coupled Loop Antennas as a Compact Building Block for Eight-Antenna MIMO Array in the Future," IEEE Trans. Antennas Propag. >, no. c, pp. 1-14, 2017.

[38]R. M. Rudish et al., "3 . 6-GHz 10-ANTENNA ARRAY FOR MIMO OPERATION IN THE," vol. 57, no. 7, pp. 1699-1705, 2015.

[39] Kin-Lu Wong, J.-Y. Lu, L.-Y. Chen, W.-Y. Li, and Y.-L. Ban3, "8Antenna And 16-Antenna Arrays Using The Quad-Antenna Linear Array As A Building Block For The 3 . 5-Ghz Lte Mimo Operation In The Smartphone," Microw. Opt. Technol. Lett., vol. 57, no. 7, pp. 174-181, 2015.

[40]M. A. Al-tarifi, M. S. Sharawi, and A. Shamim, "Massive MIMO antenna system for $5 \mathrm{G}$ base stations with directive ports and switched beamsteering capabilities," pp. 1709-1718, 2018. 